\title{
Effectiveness of Geo-Energy Usage during Underground Mining of Deposits
} KHOMENKO Oleh ${ }^{1, a^{*}}$, KONONENKO Maxim ${ }^{1, b}$ and ASTAFIEV Denys ${ }^{1, \mathrm{c}}$

\author{
${ }^{1}$ National Mining University, Dnipropetrovsk, Ukraine \\ a rudana.in.ua@gmail.com; b $k$ mn@mail.ru; ${ }^{c}$ astden@yahoo.com
}

\begin{abstract}
Keywords: rock pressure energy, stress-strain state of rocks, synergetic research methods, preventive capsule of an excavation, methodological principles of control, geo-energy technologies of mining.
\end{abstract}

\begin{abstract}
Topicality of rock pressure energy usage in technologies of underground mining of deposits is revealed. Methodology of geo-energy processes research in the interior of the Earth is described. Energy theory of zonal capsulation parameters research by massif of underground workings is proposed. Results verification of theoretical research is executed by laboratory and industrial tests conducting. Economic and mathematical model of determination of unit costs on types of mining operations is substantiated and volumes of savings during usage of geo-energy during mining operations conducting are determined.
\end{abstract}

\section{Introduction}

Globalization of the world economy lays down hard conditions on conservation of energy in a production system and consumption, optimizing the usage of natural resources of the planet by the principles of international integration. In such conditions the profit of the state is determined by efficiency and volumes of mining extraction. Thus, explored reserves of ore fields put Ukraine on leading position in the world, however parts in world amount of iron, uranium and manganese ores production don't exceed 6\%. The existing low level of technologies of ore fields mining significantly reduces competitiveness of native mining industry in domestic and foreign markets.

Scientists from Ukraine, Russia, Germany, Austria, Switzerland, France, England, USA, Canada, RSA and other countries of the world, were actively engaged in development of underground mining technologies. In the majority, researchers considered changes of massif intensity on extent of influence on support parameters and development systems. The applied format of the majority of scientific developments which were based on the principle of counteraction to the increasing energy of rock pressure set the purpose just to minimize costs for production. Such approach made impossible disclosure of physical essence of zonal disintegration of rocks phenomenon which is appeared around one and all underground developments It event suspended a little development of fundamental theories about rock pressure. For the last few decades it is became a considerable barrier on the way of creation of new hypotheses, theories or methods which would describe or modelling zonal structuring of the massif around mine workings.

During this time, mining depths of native deposits reached to a point of $1500 \mathrm{~m}$ that led to significant deterioration in geodynamic conditions of extraction. The elastic potential energy of the Ukrainian crystal board began to be shown not only in the form of peelings and balm stones formation and in the form of rock bursts, pressure bumps and earthquakes of various amplitude. It led to losses of mine workings and minerals stocks, damage of objects on surface and interiors, and, unfortunately, to traumatizing and death of people. Therefore, significant increase in efficiency and ore raw materials volumes of production is impossible without disclosure of essence of zone structuring of the massif around mine workings and the description of processes and regularities of this phenomenal event, reasons for the principles of natural factors management and their usage in geo-energy technologies of mining deposits for many years remained an unresolved scientific and practical problem [1]. 


\section{Methodological approach}

Improvement of classification of research methods of rocks stress-strain state by means of development and implementation of synergetic group of the methods including entropy, thermodynamic and energy approaches has allowed to investigate processes of power exchange in the rocks massif and regular transformations of one types of energy into others. The existing possibilities of an entropy method as parts of the thermodynamic theory are consisted in opportunities of description of thermodynamic balance in rocks and reversible deformations in undisturbed massif of rocks (V. Lavrinenko), and also exchange of entropy and redistributions of energy flows in the rock massif (O. Khomenko) [2]. The thermodynamic method allowed to determine a shape and sizes of unloading zones of stresses around mine workings, the potential and actual stresses, areas of massif destruction in unloading zones (V. Lavrinenko) [3]. The energy method allowed to determine a shape and sizes of zones of thermodynamic balance of energy, condition of zones transition into energy disbalance condition, quantity of energy zones in protective capsule and the minor factors of massif stresses around mine workings (O. Khomenko) [4]. The rock massif that creates protective capsule around development mine workings is represented as elliptic cylinder, but for stopping chamber as a rotation ellipsoid. Accuracy of executed calculations is confirmed by comparison of the obtained data method of unloading and calculated values of elastic deformations of rocks at depths up to $1200 \mathrm{~m}$ in deposits of the "Oktyabrska" and "Ternivska" mines of PJSC "KryvorizskyIron Ore Plant" and is equal to 3 - 5\%. The calculated and experimentally established density of rocks under the pressure up to $1,5 \cdot 10^{3} \mathrm{MPa}$ differ among themselves on average for $1.32 \%$, but density of minerals on $2.15 \%$. Values of relative volume deformation of minerals with a pressure up to $4 \cdot 10^{3} \mathrm{MPa}$ were compared with experimental data for conditions of high pressure, and the difference didn't exceed $7.9-10.6 \%$, but measured and calculated velocities of distribution of longitudinal elastic waves in rock massif that hadn't broken by mining operations differed for $6-8 \%$ [5].

Research of parameters of energy zones on physical models were carried out for the purpose of confirmation and visualization of the phenomenon of zone capsulation of underground mine workings. Laboratory research were carried out by means of a method of equivalent materials which allowed to visualize primary zones, but with some violation of sizes and shapes down. Selection of equivalent material was made by means of compressive resistance determination $(0.60$ $-0.70 \mathrm{MPa})$, elastic modulus $\left(0.421 \cdot 10^{5} \mathrm{MPa}\right)$, specific weight $(0.16-0.20 \mathrm{MPa})$ and Poisson ratio (0.33) on cylindrical samples with help of a digital press of KC-200/EUR of company "Tecnotest" (Modena, Italy). Optical-polarization materials (epoxide resin) showed already secondary zones, but with some violation of sizes, shapes and centering with mine workings across and vertically. Conductive materials (resistance paper) were simulated primary zones, but with violation of stresses, sizes and shapes across. Determination of separate zones position was carried out according to the analysis of stresses changing of the massif. Analysis of the phenomenon of zone disintegration of rocks showed that a watershed of zones is the value of the massif stresses corresponding to size $\gamma H$ [6]. Results of physical modeling showed the following reliability of the relative sizes of the energy zones, received by means of equivalent and optical-polarization materials and was equal to $77.5 \%$, optical-polarization and conductive materials $-86.0 \%$, conductive and equivalent ones $-96.0 \%$. The variability of data varies ranging from 82.0 to $100 \%$, with an average reliability of $91.0 \%$ [6].

The research of processes of zonal capsulation of massif is executed by means of full-scale experiments which were made on levels 665, 690 and $715 \mathrm{~m}$ of "Ekspluatuaciina" mine PJSC "Zaporizsky Iron Ore Plant" (Dneprorudny city), horizons of 1008 and $1050 \mathrm{~m}$ of "Ternivska" mine of PJSC "KryvorizskyIron Ore Plant" (Kryvyi Rih), horizons of 507 and $522 \mathrm{~m}$ of "Smolinska" mineSE "Vostochny Mining and Processing Plant" (Zhovtiwody city) with the usage of observation and estimation methods, underground surveying, massif unloading, deformation of boreholes and downhole fixed points. The analysis of results showed that change of penetration depth of stoping chambers contours changes generally on power-law dependences, but development mine workings that adjoining to cameras - on exponential ones. Authenticity of values in received equations of 
deformation depth of mine workings contour is fluctuated from 88.0 to $99.0 \%$, with an average value of $95.83 \%$ which indicates on rather high accuracy of the obtained industrial data. Furthermore, it shows the high reliability of boundary values changing of the relative penetration depth of massif which is situated at the level of $81.22-86.7 \%$ Authenticity of results on all range of the received values of penetration depth of massif are at the level of $96.0 \%$. Data on thirty six development workings and twenty five stoping chambers that located in the range of depths of 507 $1008 \mathrm{~m}$ allowed to set ellipsoidal shape of boundaries of workings contour deformation. Other forms of manifestation of massif zonal capsulation factors weren't researched [7].

The analysis of compliance of widely applied and new scientific and production principles of management of massif energy state was executed for estimation the level of energy saving by technology solutions. Modern scientific and production representations on which the majority of domestic and foreign mining of mineral deposits technologies providing stability of mine workings according two basic principles. The first is counteraction of support to destruction of bearing massif due to matching of support types, parameters of installation and conditions of their exploitation. The second one is the prevention (equilibration) of massif destruction by means of equilibration stability of the massif with sizes, shape and pathways of mine workings underlay. Complication of the mining conditions connected with increase in depth of mining operations caused adequate change of support designs and parameters of development systems only for the purpose of costs minimization so far. The problem of energy usage of volumetric compression of rocks as the main resource in increasing efficiency of mine workings exploitation, qualities of their bolting and maintenance remained unresolved before establishment by the author regularities of management of an energy condition of the protective capsules which are created around mine workings that allowed to develop the resource-saving technology solutions which are based on the new principles of management of an energy condition of the massif. The order of principles usage discloses evolution of technologies development of mine workings maintenance and protection. So, one of the first technology solutions which was widely adopted and using nowadays is a counteraction to destruction of the massif due to matching of types, parameters and service conditions of support. Using this principle, the task of repulse of the developing deformations and movements in the massif is implemented, generally during development mine workings drivage. Further it was noticed that at a certain stage, active destruction of rocks is faded, and mine working purchases steady contours that became an impulse for creation the new principle. The principle of an equilibration of rock pressure parameters with sizes and shape of mine workings found broad application during mining of stopping chambers and development workings without support. The principle of contribution to rocks destruction is implemented generally during drilling-and-blasting operations conducting. The resource-saving problem is solved by means of areas of intensive deformation of the massif collapsing. Elimination of destructions is possible at giving steady contours to exposures of development and stopping chambers to the corresponding parameters of rock pressure. In addition, effective usage of this principle is possible during mine workings underlay in areas of the lowered intensity of the massif, i.e. on a border of energy zones in which the level of rock pressure corresponds to a condition of undisturbed rock massif. The principle of transferring is used in technology solutions with the highest level of rock energy usage due to destruction process management which are transferred deep into the massif [8].

Each of the described principles rocks condition management in protective capsule of working uses various relative amount of energy of the massif. It is necessary to find a difference between vertical pressure of the massif on support and size of repulse that created by bolting system of working for determination of this amount of energy during the bolting and maintenance of mine workings. For this purpose, we will use the express technique based on the accounting of changing of power zones shapes $\lambda$. Reduction of coefficient $\lambda$ from 1 to 0 displays increase of rock pressure on mine working support which size is defined as the volume of the massif concluded in near-thecontour power zone on $1 \mathrm{~m}^{2}$. It possessed as a difference between a vertical half shaft of near-thecontour zone and a half of height of development $0.5 \mathrm{~h}$ or stopping $0.5 l_{\text {bay }}$ mine workings, $\mathrm{MPa}$

$$
P_{m}=\gamma(a-0.5 h) \text {. }
$$


Boundary value is stability of a mine working at which the minimum value $\lambda$ is accepted equal 0.5 that corresponds to usage of an equilibration principles, contribution and elimination. If value $\lambda$ approaches to 0.5 , then pressure of rocks on support significantly increases and predetermines application during developing of bolting and supporting systems and counteraction. Calculations are shown that, for instance, for development workings with hardness of $80 \mathrm{MPa}$, value $\lambda=0.9-a=$ $0.44 \mathrm{~m}$, at $0.8-a=0.68 \mathrm{~m}$, at $0.7-a=1.0 \mathrm{~m}$, at $0.6-a=1.42 \mathrm{~m}$, at $0.5-a=2.0 \mathrm{~m}$ and at $0.1-a=$ $16 \mathrm{~m}$ [9]. These values are in twice higher on average for stoping workings. In addition, the relative amount of used energy is in the equivalent relation to massif pressure on a contour of working (Fig. 1).

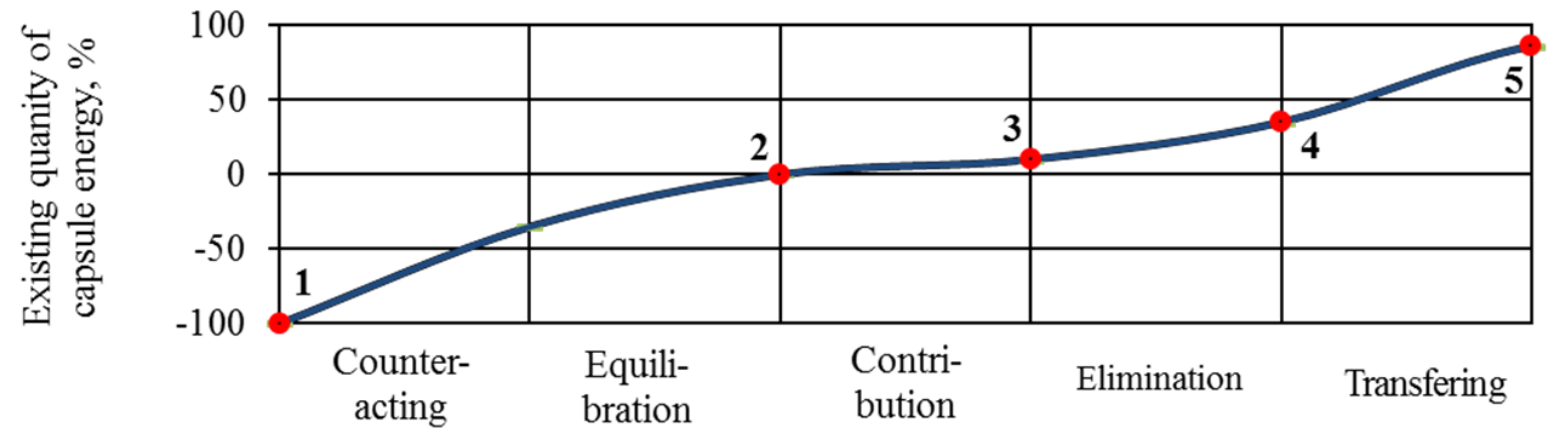

Principle of capsule energy management

Fig. 1: Graphical interpretation of principles of protective capsule energy management:

$1-5$ - key points of protective capsule energy interaction with energy of mine working support pressing.

From Fig. 1 it is visible that the technical facilities of bolting which are based on traditionally applied principle of counteraction don't use energy of the massif, but on the contrary, for counteraction of this energy spend it in equivalent or often the exceeding amount, according to safety margin of support $n$, i.e. $n=1$ - counteraction $100 \%, n=2-200 \%$, etc. The principle of an equilibration, using balance between factors of massif's energy, on the one hand, both the sizes and shape of mine workings, with another, allows to find balance between them and practically doesn't use energy for bolting and maintenance of workings $(0-10.0 \%)$. The principles of contribution and elimination are close on the level of used energy of the massif $(10.0-35.0 \%)$. The difference is that the principle of contribution is applied to stopping mine workings during production of mining operations, and the principle of elimination at preserving stability of development mine workings. The most effective methodological principle is the principle of transferring which allows to use up to $86 \%$ of massif's energy, application of self-regulating anchor support which neutralizes convergence of the massif due to energy of divergence according to parabolic-hyperbolic law. The maximum economic effect is reached at combination of several principles in one technology solution. This joint usage of steady form and self-regulating support in the plane of a face and in cross-section of development mine workings or application of a steady form and anchor bolting of stopping chambers, etc. [10].

\section{Economic and mathematical model}

For accomplishment of effective comparison of various technology solutions on preparation methods, cutting and mining of blocks or assessment of separate engineering procedures during usage of various complexes of equipment were determined cost value as for separate work types, and in general on development system [11]. The technique included determination of the main costs connected with conducting of development and cutting workings and accomplishment of stopping operations. Prime cost of production is calculated on mining unit in general belongs to $1 \mathrm{t}$ of the extracted ore mass. The structure of prime cost includes the following cost elements: the main and additional salary of workers and engineering staff workers, 
charges on payroll, materials and energy costs, amortization expenses and repair costs, face equipment support. The basis for determination of cost value is the weighted average indicators on an expense of a labor power, materials and energy, the number of mechanisms and the amortization expenses and also repair costs and equipment support. The calculation procedure included determination of specific costs for $1 \mathrm{t}$ extracted ore that is the relation of a specific cost type on visible extraction of mineral on the block or by a separate type of development or stoping operations (mine workings drivage, undercutting or cutting of chamber stocks), $\$$

$$
P_{s . e}=\frac{\mathrm{FS}_{\text {base }}+\mathrm{FS}_{a d d}+O_{s o c}+F S_{T E E}+C_{m}+C_{e l .}+C_{\text {comp.air }}+A+E_{e . r .}}{A_{\text {bal }}},
$$

where $F S_{\text {base }}$ - fund of the base salary by occupation, $\$ ; F S_{\text {add }}$ - additional salary, $\$ ; O_{\text {soc }}$ - unified social tax, $\$ ; F S_{T E E}$ - fund of salary of engineering and technical and engineering employees during mining operations conducting, $\$ ; C_{m}$ - materials cost, $\$ ; C_{e l}$. electricity cost, $\$ ; C_{\text {comp.air }}-$ compressed air cost, $\$ ; A$ - amortization expenses on the period of equipment processing, $\$ ; E_{\text {e.r. }}-$ expenses on repair and maintenance of equipment during mining operations conducting, $\$ ; A_{\text {bal. }}-$ balance stocks of extracted block (deposit), tons.

Usage of up to $86 \%$ of relative amount of energy concentrated in capsules of development mine workings increases specific cost efficiency of drivage operations on $1 \mathrm{~m}$ that allows to save $\$ 0.05$ for $1 \mathrm{~m}$ of development working with safety face anchor support at mines of PJSC "Marganetsky IOP"; to decrease costs on $\$ 0.05$ for $1 \mathrm{~m}$ of development working with a steady shape of bedding of a face and cross-section, and to $\$ 7.4$ for $1 \mathrm{~m}$ during determination of rational places of drilling roadways bedding at mines of PJSC "Kryvorizsky IOP"; to save $\$ 97.29$ for $1 \mathrm{~m}$ during drivage and cutting of mining blocks with usage of steady shape and rational bolting of workings at mines of PJSC "Zaporizsky IOP"; to decrease costs to $\$ 253.62$ for $1 \mathrm{~m}$ during drivage of workings with usage of the combined self-regulating bolting at mines of PJSC "Kryvorizsky IOP" (Fig. 2).


Fig. 2: Regular it y of specific prime cost of drivage operations from used energy of the massif

Usage of up to $10 \%$ relative amount of the energy that concentrated around stoping chambers on linear dependence increases specific cost efficiency of stoping operations and will allow to cut down expenses up to $\$ 0.001$ for $1 \mathrm{t}$ for primary and secondary crushing of ore due to change of the direction of drilling of operational boreholes on the mines of PJSC "Zaporizsky IOP"; to decrease costs on $\$ 0.15$ for $1 \mathrm{t}$ for drilling, loading and secondary crushing of ore due to increase in distance between operational boreholes at mines of SE "Vostochny MPP"; to cut down expenses on $\$ 0.19$ for $1 \mathrm{t}$ during increasing in stability of ore and rock exposures in stoping chambers, decreasing in losses and impoverishment of ore due to giving of a steady shape to structural elements of blocks in mines of PJSC "Kryvorizsky IOP; to decrease costs for $\$ 0.21$ for $1 \mathrm{t}$ with giving of a steady shape of developments of cutting undercutting that excludes unauthorized collapses of ore in stopping chambers at mines of PJSC "Zaporizsky IOP" [12]. 


\section{Conclusions}

1. The analysis of rock pressure energy usage problem in mining of deposits technologies has shown considerable reserves in economy of facilities. Creation of synergetic methods of a research of geo-energy has allowed to investigate parameters of zone capsulation by the massif of underground workings. Definition of components of natural power balance has allowed to establish degree dependences of increasing of entropy influence part to $95 \%$ of the overall power balance of external stresses on the example of rocks of Kryvorizsky Iron Ore basin.

2. Modeling of a wide range of mine workings drivage has allowed to establish the sizes and shape of power zones. It is established that the broken massif forms the safety capsule around mine working due to change of gradients of geo-energy factors. These processes lead to formation of circle zones of thermodynamic balance and imbalance of energy. Checking of modeling results of zonal capsulation by the massif of underground workings on laboratory models which has shown reliability on more than $89 \%$ is executed. The analysis of the areas of zonal deformation of the massif that revealed by natural research has shown reliability of the obtained data on not less than $84 \%$.

3. On the basis of the proposed principles of management of protective capsule energy: counteraction, equilibrations, contribution, elimination and transfering, geo-energy approaches for designing of pathways of development workings are formulated and parameters of stoping workings in conditions of capsulation are substantiated. The share of rock pressure energy that directed on maintenance of mine workings or mining of mineral deposits is described by parabolic-hyperbolic dependence. It allows to achieve economy of resources up to $37 \%$ by means of usage up to $86 \%$ of rock pressure energy.

\section{References}

[1] Kaydo,I.I. O prirode yavleniya zonal'noy dezintegratsii gornykh porod vokrug podzemnykh vyrabotok (gipoteza), Gornyy informatsionno-analiticheskiy byulleten', 1. 16-21. (2009).

[2] LavrinenkoV.F., LysakV.I. Metod opredeleniya nachal'nogo napryazhennogo sostoyaniya massivov skal'nykh gornykh porod, Razrabotka rudnykh mestorozhdeniy, 24. 16-20. (1977).

[3] LavrinenkoV.F., LysakV.I. Fizicheskie protsessy v massive porod pri narushenii ravnovesiya, Izvestievuzov. Gornyyzhurnal, 1, 1-6. (1993).

[4] Khomenko O. Implementation of energy method in study of zonal disintegration of rocks Scientific Bulletin of National Mining University, 4, 44-54. (2012).

[5] Khomenko O.E. Upravlenie energiey gornykh porod pri podzemnoy razrabotke rud, Gornyyzhurnal. Chernyemetally, Spetsvypusk, 41-43. (2010).

[6] Shashenko, A., Gapieiev, S., Solodyankin, A. Numerical simulation of the elastic-plastic state of rock mass around horizontal workings. Archives of Mining Sciences, (54) 2, 341-348. (2009).

[7] Khomenko O.Ye., Maltsev D.V. Laboratory research of influence of face area dimensions on the state of uranium ore layers being broken. Scientific Bulletin of National Mining University, 2, 31-37. (2013).

[8] Khomenko, O., Kononenko, M., \& Netecha, M. Industrial research into massif zonal fragmentation around mine workings. Mining of Mineral Deposits, 10 (1), 50-56. (2016).

[9] Sdvyzhkova, O., Babets, D., Kravchenko, K., Smirnov, A. Determination of the displacements of rock mass nearby the dismantling chamber under effect of plow longwall. Scientific bulletin of National Mining University, 2, 34-42. (2016). 
[10] Khomenko O.E. Geoenergetika podzemnoy razrabotki rudnykh mestorozhdeniy: monografiya, 242. (2016).

[11] Stupnik, M., Kalinichenko, V., Pysmennyi, S., Fedko, M., \& Kalinichenko, O. Method of simulation of rock mass stability in laboratory conditions on equivalent materials. Mining of Mineral Deposits, 10 (3), 46-51. (2016).

[12] Astafiev, D., Niedbalski, Z., Leschhorn, F., \& Tymoshenko, Ye. Technological, economic and ecological aspects of selective coal mining from ultra-thin seams in conditions of Ukraine. Mining of Mineral Deposits, 10 (1), 83-88. (2016). 